\title{
Chapter 12 \\ The Sydney Language on Our Campuses and in Our Curriculum
}

\author{
Rosanne Quinnell, Jakelin Troy, and Matthew Poll
}

\begin{abstract}
Now my motivations ... so, my aspirations for all of this is of course first and foremost, I want to learn my own language again, I want to have that knowledge point. People ask me how to speak, "do you speak Aboriginal?" I feel like that's a really weird question, but yes, I can. Second of all, I want to bring that back to my family. I want them to have that same feeling. Going one level higher, I don't want there to be a single person left in Sydney who was convinced that my language is dead. I want everyone in Sydney to have the opportunity to learn this language if they so choose. I want them to be able to learn at school or be able to go to a tape or a university, do linguistics, majoring in Gadigal language. That would be incredible.... I think it's wild that in high school, I learned Spanish and Italian and I don't remember any of it ... I didn't feel any connection to it whatsoever (Joel Davison, cited in Troy \& Poll, 2018).
\end{abstract}

\section{Introduction}

Language lies at the heart of cultural identity. Prior to colonisation in 1788, there were more than 250 Indigenous Australian languages in Australia (Walsh, 1993; Walsh, Marmion, \& Troy, 2014). Up until the late nineteenth and early twentieth centuries, prohibitions were in place that banned most Aboriginal people from speaking their

The original version of this chapter was revised: The belated correction has been incorporated. The correction to this chapter is available at https://doi.org/10.1007/978-981-15-5362-2_20

R. Quinnell ( $\square)$

Faculty of Science, The University of Sydney, Sydney, NSW, Australia

e-mail: Rosanne.Quinnell@sydney.edu.au

J. Troy

Aboriginal and Torres Strait Islander Research, The University of Sydney, Sydney, NSW,

Australia

M. Poll

University Museums, The University of Sydney, Sydney, NSW, Australia

(c) The Author(s) 2020, corrected publication 2021

J. Frawley et al. (eds.), Cultural Competence and the Higher Education Sector,

https://doi.org/10.1007/978-981-15-5362-2_12 
own languages (Maier, 2010; Reid, 2010). Many of the "sleeping"1 pre-contact languages are undergoing revitalisation (Hobson et al., 2010), a process that requires respectful action and acknowledgement of Aboriginal and Torres Strait Islander people's deep connection to the cultural, philosophical and spiritual concepts of land and land tenure. In 2016, the United Nations Educational, Scientific and Cultural Organization (UNESCO) made this declaration:

It is through language that we communicate with the world, define our identity, express our history and culture, learn, defend our human rights and participate in all aspects of society, to name but a few. Through language, people preserve their community's history, customs and traditions, memory, unique modes of thinking, meaning and expression. They also use it to construct their future. (UNESCO, 2016)

To highlight the importance of Indigenous languages in strengthening the position of Indigenous cultures on a global scale, UNESCO declared 2019 the year of Indigenous languages. At the University of Sydney, like institutions in other parts of Australia, we are recognising our responsibility to acknowledge and preserve Aboriginal Australia's heritage. At the local level, the focus on Indigenous languages on our campuses provides opportunities to connect the higher education community with Indigenous culture. We offer these connections to Indigenous language through the creation of interdisciplinary collaborations across the arts and the sciences, spanning linguistics, botany, art and museum studies. The University grounds cover urban areas (inner-city and suburban) and regional areas across Australia (e.g. Broken Hill, Lismore, Dubbo, Orange, Camden, Nowley and Narrabri). The "Sydney Language" is the language of the Gadigal people, the traditional custodians of the University of Sydney's main inner-city campus. The Sydney Language, spoken for tens of thousands of years pre-colonisation, is in revival, and the survival of this language is a proactive declaration of the strong living presence of the Gadigal people in the University's community.

Sydney has been the realm of Aboriginal people for tens of thousands of years. The harbour was referred to as Guru, or “deep water". In 1788, the British invaded at Waran (the place we now call Sydney Cove, Port Jackson). The lands of the Gadigal people stretched along the southern side of Port Jackson (Sydney Harbour), from South Head to around what is now known as Petersham, and to the Cooks River to the south (Attenbrow, 2009a). Although much of Sydney was renamed post-contact, around and about the city and surrounding suburbs language remnants survive. In this way, the words of the Sydney Aboriginal languages still permeate the Australian vernacular. Suburbs, beaches, street names are adorned with Aboriginal words that have persisted into the twenty-first century, despite many of the original associations (i.e. the words and meanings) having become disassociated. The persistence of these words creates bridges between the present and past. Reinstating the original place names and having these names enter common usage is one way to enable the Sydney Language to be preserved (Troy \& Walsh, 2009). The ways Aboriginal language words sit in sentences, for example, in place names and the names of flora and fauna,

\footnotetext{
${ }^{1}$ Rather than being referred to as a "dead" language, the term for Indigenous languages in the process of revitalisation is "sleeping" (Hobson et al., 2010).
} 
are a testament to the resilience of Indigenous language and reinforce the connection between the Gadigal landscape and language over countless generations.

Sydney's Aboriginal communities were some of the first to be colonised, and today, Sydney is a diaspora of Aboriginal and Torres Strait Islander peoples from many communities across Australia. Many stories of resilience and determination have had their beginnings here. Sydney has been the site of cultural, political and artistic revolutions that have placed the rights of Aboriginal and Torres Strait Islander peoples on the national agenda. The national significance and political importance of campaigns that began at the University specifically include the Students Action for Aborigines in the 1960s, and the gravity of the Freedom Ride of 1965 cannot be understated. Both were led by Charles Perkins, ${ }^{2}$ an Arrernte man born in Alice Springs, and both had significant impacts with respect to the positive outcome in the 1967 Referendum (Nugent, 2013; National Museum of Australia, 2014).

Sitting closer to the curriculum, the Koori Centre was established at the University of Sydney in the late 1980s to support Aboriginal and Torres Strait Islander students enrolled at the University, and to teach into the mainstream curriculum, by offering specialised knowledge on Aboriginal and Torres Strait Islander affairs and education. A national focus on cultural competence in university curricula was declared by Universities Australia (UA) in 2011 (2011a, 2011b), and, in response, the University revised and broadened their cultural competence remit in the curriculum, and across the campus as a whole, in 2012. The University of Sydney closed the Koori Centre and established the National Centre for Cultural Competence (NCCC) in 2014 with a focus on the broadscale adoption of a cultural competence pedagogy (Sherwood \& Russell-Mundine, 2017) across the University, where Aboriginal and Torres Strait Islander students are culturally safe and Indigenous Knowledges (IKs) are privileged in their own right. Cultural competence is a "graduate quality" and is highlighted in the University's 2016-2020 strategic plan (The University of Sydney, 2016a).

There is power in language to create spaces where the notion of cultural competence can be discussed. The University of Sydney has become an active site of major reconstruction of suppressed histories and linguistic reclamations by contemporary Aboriginal and Torres Strait Island peoples.

Language is pivotal in the areas of human rights protection, good governance, peace building, reconciliation, and sustainable development. A person's right to use his or her chosen language is a prerequisite for freedom of thought, opinion and expression, access to education and information, employment, building inclusive societies, and other values enshrined in the Universal Declaration of Human Rights. (UNESCO, 2018)

A wealth of historical documents with linguistic notations from the First Fleet, which arrived in Sydney 1788, have been used for language reconstruction, the linguistic notions being particularly crucial as there are few native speakers of the Sydney Language. In the 1980s, Jakelin Troy, a Ngarigu woman, meticulously

\footnotetext{
${ }^{2}$ To honour Charles Perkins and to continue to focus attention on Indigenous and non-Indigenous race relations, an annual oration, the Charles Perkins Memorial AO Oration, has been held at the University since 2001. The Charles Perkins portrait, painted by Daniel Boyd in 2017, hangs in the Charles Perkins Centre at the University of Sydney.
} 
scoured historical records of the early Sydney colony to create a dictionary of the Sydney Language (Troy, 1994). This work breathed life back into the Sydney Language and was able to offer language framed by a reconstruction of Sydney's Aboriginal past by drawing together many pieces of historical information from diverse sources including diaries, notebooks, governmental reports and people's private correspondences. The several thousands of words sourced from historical material created an assemblage of what words sounded like, to the ears of English speakers. This is an important distinction as when there are no fluent speakers of a language, its reconstruction relies on the crucial aspect of pronunciation. This approach to uncovering languages offers evidence not only of where the language comes from, but also who was able to participate in the teaching and sharing of language. These notebooks are archived in libraries and museums in Australia and overseas, and although the attribution for authorship of these notebooks on language rarely acknowledges the source, there are a few notable exceptions.

\section{Patyegarang and the Gift of Language}

There are about 27 clan groups in the Sydney area, making this area socially complex. In the historical records, no name was given to the language of Sydney, with the "Sydney Language" being used to describe the language that was likely common to these clans (Troy, 1992, 2018); the language is also referred to, for example, as the Gadigal language by the Gadigal people, and the Dharug language. The Sydney Language is in the Pama-Nyungan language family which is the most widespread language family in Australia (Bowern \& Atkinson, 2012).

In Sydney, at first contact, there were a few notable teachers, mostly Gadigal women, who shared their language (Troy, 1992, 2018). Patyegarang, named after the eastern grey kangaroo, or badagarang, taught her language to Lieutenant Dawes, an officer of the First Fleet. for the Endeavour RiverDawes was sent out to Sydney to make astronomical and weather observations. While Patyegarang, no doubt, had friends among the other officers of the First Fleet, Dawes, in particular, became an early language champion among his own people, the English colonial invaders. Like many Aboriginal women, Patyegarang was a cultural intermediary for her people; at that time, Aboriginal women were often the people who shared language and cultural knowledge. This was because the women, especially the young women, were more flexible than the men with respect to forming social relationships (Troy, 1992). Boys becoming men were more constricted than women regarding to whom they could talk, and as men grew older and more senior, they became more socially constricted (Troy, 2018). Women's social status and social positions also changed with age, but based on historical records, it would seem that women had a very strong role in brokering relationships between peoples.

Patyegarang met and talked with William Dawes at a place known as Dawes Point Battery, now dual-named with the Gadigal place name Tar-ra (Troy \& Walsh, 2009). Tar-ra is where Sydney Harbour Bridge comes across to the south side of the city. 


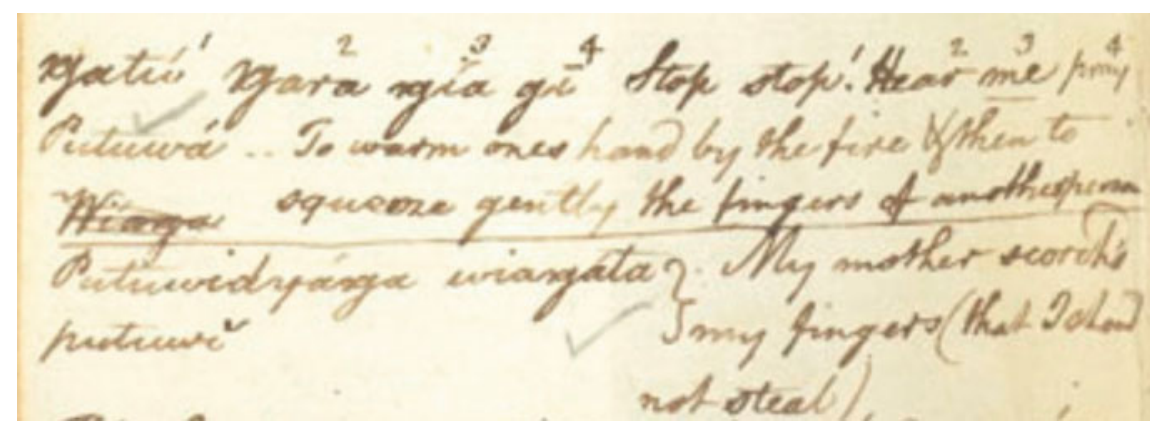

Fig. 12.1 Extract from Dawes notebook (Dawes et al., 2009)

On the site, there is a little stone observatory, built by Dawes, where he made his observations of celestial bodies. Specifically, Dawes was waiting to observe a comet that was predicted to appear in 1788. Dawes sat at Tar-ra and talked to the young woman, Patyegarang, with both languages being shared.

Patyegarang and Dawes talked about the patterns in the natural environment. Applying botanical knowledge was part of everyday practice, and women had a lot of engagement with plants; for example, they made string bags out of the fibre. As a woman in her community, Patyegarang was responsible for making fishing lines out of kurrajong [Brachychiton populneus (Schott \& Endl) R.Br. Family Malvaceae] and helping to build canoes, as well as building the fires that went onto the canoes where they would catch and cook fish.

The conversations between Patyegarang and William Dawes, where Patyegarang gifted her language, included lists of plants, their uses and, in many instances, the names by which those plants were known by the Aboriginal people of the Sydney region. Dawes recorded the information provided by Patyegarang in his notebooks (Dawes, Rayner, \& Brown, 2009). Dawes' notebooks record Patyegarang's generosity with her language and include content that speaks of the trusting relationship between the two. One entry from Dawes' notebooks is as follows. "Putuwó: To warm one's hand by the fire \& then to squeeze gently the fingers of another person" (see Fig. 12.1).

\section{Reimagining Patyegarang's Gift of Language in Contemporary Educational Contexts}

Relinking Indigenous languages with artefacts has become a global movement particularly in the contexts of museums (Simpson, 2009), as has relinking Aboriginal place names back to their origins (Attenbrow, 2009b; Troy \& Walsh, 2009). Preserving and offering the Sydney Language on the University of Sydney's campuses is being undertaken in new and innovating ways. Like the scenario between Patyegarang and Dawes, these offerings are the result of a transdisciplinary and transcultural collaboration. 
We have harnessed mobile technology to offer plant names in the Sydney Language, and so Patyegarang's botanical vocabulary has become accessible to our students (particularly students in biology), staff and the community at large, via the "Campus Flora app". Using the Campus Flora app to identify plants by the names as known by Patyegarang and her people for millennia is enabling language revitalisation on lands where there have been generational observations, learnings and teachings by the Gadigal. In offering the Sydney Language, Campus Flora teaches experiential-based knowledge of place and that knowledge and language are interwoven.

Oral histories in language are able to transmit and preserve careful environmental observations—observations that have been aggregated across generations.

Oral traditions, especially contrasted with written history, are typically portrayed as inaccurate.... So can preliterate Indigenous languages tell us anything factual about the distant past, or does the transmission of historical facts become inevitably corrupted? (Reid, Nunn, \& Sharpe, 2014, p. 1)

Despite the view that written histories are more credible, the effectiveness of oral transmission of knowledge is well documented (Brown, 2013; FernándezLlamazares \& Cabeza, 2018). For example, transgenerational observations of the sea level rise, the crashing to earth of meteorites and the cosmography of the night time sky are part of a rich and complex repository of countless generations of accumulated observations, enshrined in cultural knowledges and carried by languages.

Changes in sea levels around the Australian coast are now well established. Marine geographers can now point to specific parts of the Australian coast and know with some confidence what the sea levels were at a particular time before the present.... [due to a] substantial body of Australian Aboriginal stories that appear to represent genuine and unique observations of post-glacial increases in sea level, at time depths that range from about 13,400-7500 years BP ... [making] ... the case that endangered Indigenous languages can be repositories for factual knowledge across time depths far greater than previously imagined, forcing a rethink of the ways in which such traditions have been dismissed. (Reid et al., 2014, p. 1)

Preserving the Gadigal knowledges that are embedded in the Gadigal language goes beyond meeting obligations for Indigenous cultures to be practised and expressed. There are very real ecological knowledges and knowledge transference processes across transgenerational boundaries that deserve far greater understanding than is presently the case. This is particularly relevant to knowledges that are still linked with Indigenous languages and to the knowledge post-translation.

\section{The Site of the University's Camperdown Campus}

The Camperdown campus along with Victoria Park was known to early settlers as the "kangaroo ground". "Kangaroo" is a European variant on the Murri ${ }^{3}$ word for kangaroo ("gangurru"-language: Guugu Yimithirr). The word kangaroo was

\footnotetext{
${ }^{3}$ Murris are Indigenous Australians from Queensland, north-west New South Wales; the Guugu Yimithirr language is from far north Queensland.
} 
brought into the Sydney region by Europeans with Captain Cook, when navigating the Endeavour River ${ }^{4}$ in July 1770, who documented that a kangaroo was "an Animal something less than a greyhound", and noting the name used by the local Murri people as "Kangooroo or Kanguru" (Cook \& Wharton, 1893). The Guugu Yimithirr name for "kangaroo" was imported into the colony of New South Wales by non-Aboriginal people; the Aboriginal groups around Sydney had not heard of "kangaroos" before and assumed the word also referred to sheep, horses and cows (Karskens, cited Griffiths, 2015). Early colonial officers Watkin Tench and David Collins both wrote of the agricultural potential of the "Kangooroo Ground", with Collins (1798, pp. 266267) recognising that "the ground lay well for cultivation; but it had hitherto been neglected, from its being deficient in the very essential requisite of water".

The Gadigal people regularly exploited the ecology of the "kangaroo ground" in pre-European times for food and other resources (Pearson et al., 2002). The bark of the Sally wattle (Acacia falcata Willd) could be used to stupefy fish, and the sap of the red bloodwood (Corymbia gummifera (Gaertn.) K. D. Hill \& L. A. S. Johnson) was extracted to treat fishing lines and stop them fraying. The fruit of the native cherry (Exocarpus cupressiformis Labill.) and the roots of the clover sorrel (Oxalis corniculata L.) were common sources of nutrients, while the leaves of headache vine (Clematis glycinoides DC) were often crushed and the scent inhaled to relieve headaches. The long-leaf mat rush (Lomandra longifolia Labill.), for example, would have grown on the "kangaroo grounds" and, in addition to its nectar, was a valued material for making baskets. Blue flax-lily (Dianella caerulea Sims and Dianella revoluta $\mathrm{R}$.Br.) were also valued for their fibres.

Despite there being available a reasonable level of knowledge about the precontact history of the University's campus grounds, many (or arguably most) of people in the campus community are not aware of, or not readily able to access, these cultural narratives. Strategies to make the Sydney Aboriginal narratives more evident are being enacted across the University.

\section{Language Visibility and the University's Built Environment: The Wingara Mura-Bunga Barrabugu Design Principles}

As stated, the preservation of information through oral transmission has been shown to be an incredibly reliable means of teaching (e.g. Brown, 2013; FernándezLlamazares \& Cabeza, 2018; Walsh, 2016). That culture, knowledge, law and language are inseparable, highlights the necessity of making the surviving components (words and linguistic notations) of the Gadigal language visible, reinforced and spoken. Making visible and explicitly integrating the language into future landscape design is a way of reinforcing and rearticulating the language derived from Gadigal Country. The University has design principles as part of its greater cultural competence strategy, offered through Indigenous Strategy and Services (The University of

\footnotetext{
${ }^{4}$ Wabalumbaal is the Guugu Yimithirr name for the Endeavour River.
} 
Sydney, 2012). The phrase Wingara mura-bunga barrabugu, meaning "thinking path to make tomorrow", was used to inform the University's design principles (The University of Sydney, 2016b) which are:

1. Projects should be firmly grounded in a response to place-they should be climatically and culturally responsive and explore opportunities to work with a locally informed vernacular of language, materials and craft.

2. Projects should express and convey meanings legible to both Indigenous and non-Indigenous groups in the treatment of buildings and spaces.

3. Projects should explore initiatives to rethink sharing country and develop spaces that seek to recognise shared history and co-existence.

4. Activities and spaces should be considered within the context of a larger landscape of Indigenous narratives.

We offer the following case studies as examples of how the Wingara mura-bunga barrabugu design principles have been enacted.

\section{Case Study 1: The University's Campus Flora Project: Plants and the Sydney Language}

The Campus Flora app is a technology-enabled mobile-learning (m-learning) strategy, encompassing our campuses and outdoor learning spaces for botany and ecology, throughout the life science curriculum. The app maps the plants and plant trails on University of Sydney campuses and includes image galleries for each species, along with botanical, ecological and ethnobotanical information. The first Campus Flora app was designed as a tool to support the development of the botanical literacy of biology students (Pettit, Pye, Wang, \& Quinnell, 2014a, 2014b), and as a way to place the Sydney Language back into the campus landscape.

The Campus Flora app offers locations and information for each tree on our campuses. The app supports the narratives offered by "western science", contextualises the evolutionary timelines and offers the botanical descriptions of plants, together with images to make sense of the botanical terms used in those descriptions. The Patyegarang trail, a walking trail, connects users with the language of the traditional custodians. The Campus Flora project has drawn together academics, undergraduates and professional staff from across the University, including the Sydney University Museums and the disciplines of Botany and Engineering, into a common space to co-create ecological, botanical and cultural narratives, using the plants as waypoints for the trails. These trails are shared with all members of our community and visitors to our campus (Dimon et al., 2019). The Campus Flora project has lent itself to address environmental, botanical and digital literacies, as well as offering a means to talk about cultural competence.

In 2010, the Australian Academy of Science defined the future "big challenges" for Australia as being health and well-being, infrastructure, energy, water, sustainable agriculture, climate change and preservation of biodiversity. Just as improving 
botanical literacy is critical for our biology students to prepare them to address the big challenges in ecology, making the Sydney Language visible to all students who study on our Sydney campuses provides an access point to connect with Indigenous narratives and knowledges, starting with language. Introducing science students to the language of both "western science" and the Sydney Language deepens their understanding of how the plants and landscape respond to the seasonal changes of our region. The four seasons of the northern hemisphere sit uncomfortably on our southern continent where seven or more seasons are evident in Indigenous weather knowledges (Australian Bureau of Meteorology, 2014). Observations of how the patterns in the landscape change with the seasons are common to both IKs and biology.

English (and western) scientific names-mostly in Greek and Latin-were the first languages offered in the Campus Flora app. The work of Troy (1994) was used to develop the Patyegarang Sydney Language Trail, and this was supported by the Deputy Vice-Chancellor Indigenous Strategy and Services and Campus Infrastructure Services. The information offered with the trail includes distance $(1.3 \mathrm{~km})$, estimated time to walk the trial ( $35 \mathrm{~min})$, the Gadigal names and the following:

Patyegarang was an Aboriginal woman of the Gadigal nation. She shared her culture
with Sydney colonists c. 1780 and was one of the first teachers of Aboriginal language.
This trail honours Patyegarang's generosity and offers the traditional language of this
place. Banksia integrifolia_-courriddjah; Leptospermum (tea-tree)—bunya; Melaleuca sp.
(paperbark)—gurrundurrung; Casuarina glauca_-guman; Eucalyptus (eucalypt)—yarra;
Acacia (wattle)—wadanguli; Syzygium paniculatum (brush cherry)—daguba; Livistona
australis (cabbage tree palm)_daranggara; Ficus rubiginosa (Port Jackson fig)—damun;
Syzygium smithii (lilly pilly)—midjuburi; Xanthorrhea (grass tree)—gulgadya.

In addition to the Sydney Language, the Campus Flora app now offers the names of the plants whose native distribution is China in Chinese (both Chinese characters and pinyin). To date, the languages offered in Campus Flora are the Sydney Language (offered as the Patyegarang trail), English and Chinese. In this way, we offer a process where science and other knowledge systems can occupy a shared space. To honour Patyegarang, we have offered as much of the Sydney Language as we possibly can using the plants as waypoints for a trail. A screenshot of the Patyegarang trail is offered (see Fig. 12.2) with guman (Casuarina glauca) highlighted. The legacy left by Patyegarang in the historical documents is a great springboard for language revival.

In essence, the Sydney Language trail is a contemporary rendering of Patyegarang's conversations with Dawes and Patyegarang's gift of the Sydney Language to Dawes. With the Campus Flora app, plants - either in real time or virtuallybring the Sydney Language back to the place of its origins, back to the place where it first came into being. With continued engagement, the Campus Flora app becomes a portal through which people can contribute to community narratives. This notion of plants being integral to cultural and community narratives resonates with the belief that: 


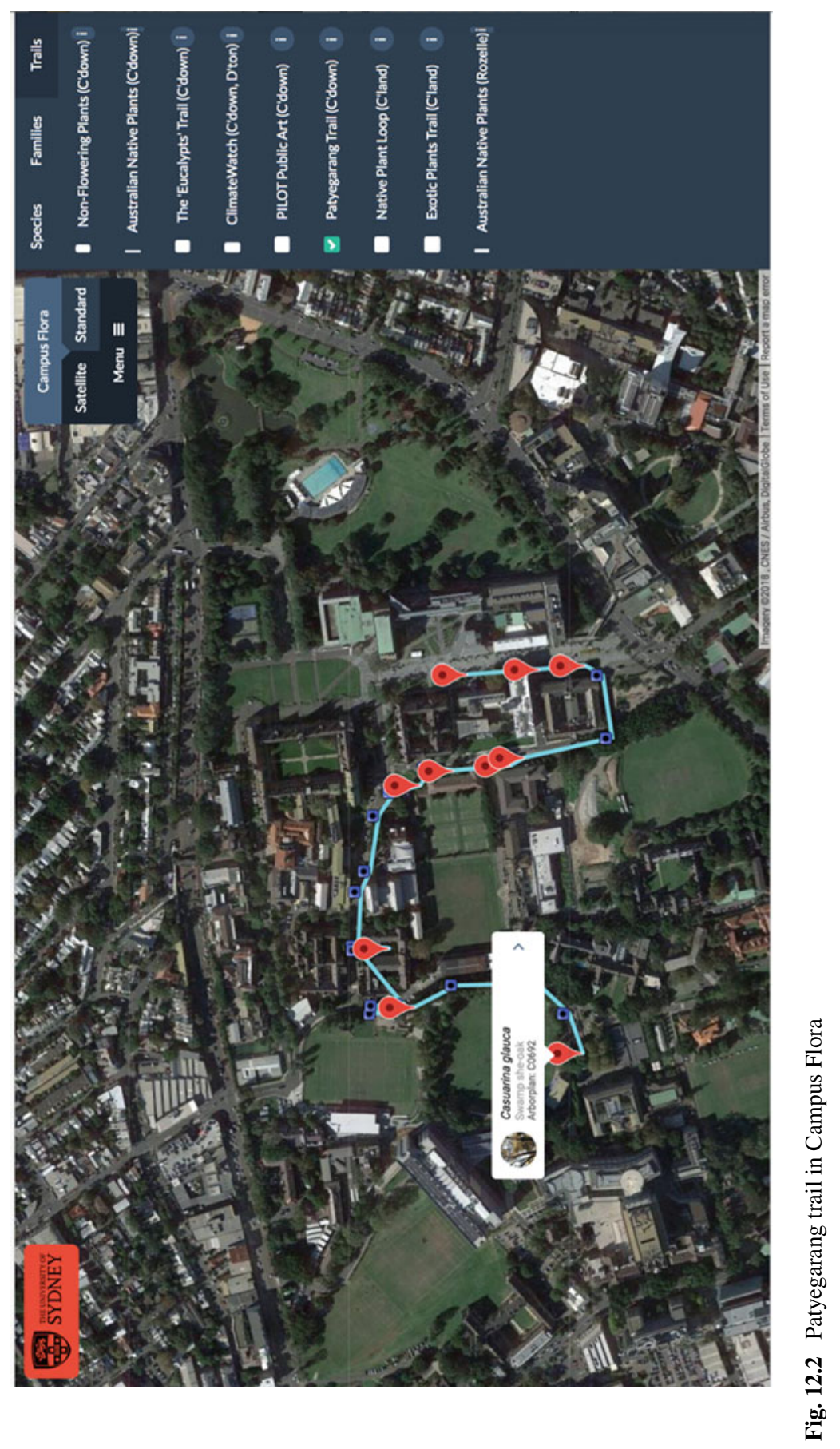


living things, be they mammals, birds, reptiles, insects or trees are our sisters and brothers and therefore we must protect them. We are their custodians. We not only share with them, we also guard them (Oodgeroo, cited Martin \& Mirraboopa, 2003, p. 209)

The groundwork of bringing the Sydney Language into sharp relief via the Campus Flora app presents a means to honour the knowledges of the Gadigal people on the campus grounds and, for the University Museums' collections, a way to imbue the museum spaces with these knowledges, through language. In offering Campus Flora outside of the strictures of a learning management system, the entire University community can use the Patyegarang trail to find, see and touch plant species that have been known to the Gadigal people for generations, and to speak their Aboriginal names. Offering an Indigenous language in a physical context, specifically through place-based learning, deepens the experience of engaging with Indigenous languages and with Indigenous Australian history, enabling a legitimate pedagogic segue between botanical narratives and an Indigenous Australian historical narrative.

\section{Case Study 2. Sydney University Museums Natural and Cultural History Collection}

The Macleay Museum began with a bequest of natural history and Indigenous cultural material to the University of Sydney in 1891. These natural and cultural collections came from the Macleay family and include material collected from the 1790s, donated for the use of the University community. In 2003, the Macleay Museum became part of Sydney University Museums, encompassing the Nicholson and Art collections, and in 2020, these three University institutions will form the Chau Chak Wing Museum within a purpose-built building on the site of the old "kangaroo ground". The transformation from a nineteenth-century museum that was primarily natural history-focused into a twenty-first-century interdisciplinary museum is charged with representing not only its own particularly unique history, but also the history of the First Nations peoples' collections. Museums have played a larger role than most in constructing unethical versions of the Aboriginal and Torres Strait Island past. The challenge for twenty-first-century museums in Australia today is in designing Aboriginal and Torres Strait Island exhibitions that prioritise Indigenous values in the locality of the museum, for example in the urbanised landscape of Sydney (Poll et al., 2018; Simpson, 2009), and that ensure cultural safety for all community members.

While the plantings around the new museum will be included in the Campus Flora app, inside the Chau Chak Wing Museum we have the opportunity to offer a large number of regional languages connected with physical objects and artefacts. Through the Museum exhibitions, we hope our audiences will come to learn geographies of "Country"; and the differences and sounds of, for example, Wiradjuri, Yolyu, Guugu Yimithirr and the Sydney Language. However, this is not just a tool for teaching about these languages, although reconnecting the language of the objectmakers and custodians with the object itself is powerful. It can also be a way for 
language to become part of the process of curation, a process whereby museums can ethically embrace the plethora of Indigenous languages and processes, aligned with the Australian Museums and Galleries Association "roadmap" (2017) for enhancing Indigenous engagement with museums and galleries.

With respect to natural history specimens, we can explore broad differences between Aboriginal taxonomies and the binomial classificatory system embraced worldwide. Aboriginal Australia's rich linguistic heritage makes this complicated: What language to use? In exhibitions within the Macleay Museum, we used the Sydney Language, reasoning that the objects and animals were being viewed here in Gadigal Country. We hope, with the active participation of language speakers, to expand upon this and slowly build up identifications for animals and objects in the language of their origin. Thus, a specimen of an eastern grey kangaroo (Macropus giganteus) acquired in far north Queensland will also be labelled "gangaruu", while the same animal collected in Sydney will be "badagarang". This should also allow people to use their own language to find things in the collection through the online search. In making the pertinent information about collections relevant to community needs, in regard to exercising sovereignty, Indigenous control of the representation of Indigenous culture can be realised.

The collection of native Australian wildlife specimens that today sit as taxidermy objects in museums across the world relied heavily on the Aboriginal knowledges of seasonal abundance, and the types of local knowledges that can only come from tens of generations of teaching and learning. First Nations intellectual properties exist in all sorts of non-object-based collections. The simple act of naming a species of plant or animal in the language of the people who knew it intimately for millennia is a small step towards decolonising the ways that the English language has colonised our reading of our natural environment. The ability to further increase the networking collections, objects and information from specific Indigenous nations and their associated language regions, that are held across multiple institutions, affords a new level of accessibility and control that can be exercised over these displaced and dislocated fragments of cultural histories.

It is in using Indigenous languages to name the Indigenous objects in the language of their makers and custodians that the University of Sydney can clearly demonstrate its commitment to reconciliation and providing a space for Sydney's Aboriginal communities to assert a sense of autonomy over how their culture is displayed in the public arena. In some exhibitions, the authentic and ethical use of language will include an added layer of security, in that aspects will only be readable by language speakers; and this in itself presents an opportunity for a demonstration of self-determination in relation to museum collections. Over time, the related Haswell zoological teaching collection at the University's School of Life and Environmental Sciences will also connect Indigenous languages to the teaching specimens in a way that is a working partnership with students (Quinnell et al., 2018). Ultimately, this strategy is a continuation of place naming, bringing the idea into the Chau Chak Wing Museum building and our teaching. 
Embedding Indigenous language and knowledges into the ways that native species have been exhibited, labelled and taught in the Sydney University Museum's education programme has been a long-term project of the Macleay Museum, used in the permanent exhibitions. In 2014 and 2015, two exhibitions explored new ways of changing our focus from a Scottish family collection, to a collection drawn from Aboriginal knowledge systems into a University education system:

1. "Written in stone" (Poll, 2015). The simple premise of Written in Stone was to take more than a century of historical collections of archaeological "evidence" and liberate it from archaeological terminologies and typographic associations. Instead of a focus on technology, our focus was on the language groups of the people who made the object. Suddenly, it seemed, the focus changed from broad classification, to seeing place through the colouration of the stone, and similarity of forms driven by the materiality. A rich diversity of the source material, trade networks and economies of exchange, as well as brilliant craftsmanship and ingenuity, all became apparent in the reconfigured "tool boxes" of each region represented in the exhibition.

2. "Dhaga Ngiyahni Ngan.Girra" (where we all meet) (Reily \& Reily-McNaboe, 2014). This re-showing of Western Plains Cultural Centre's exhibition of kangaroo skin cloaks and woven feathered headbands and belts was centred on a dramatic, large possum-skin blanket, upon which Diane Riley-McNaboe and her sister Lynette Riley ${ }^{5}$ had inscribed the botanical knowledge of their relatives and ancestors. With everything carefully co-captioned in Wiradjuri, the exhibition dramatically revealed that forced removal — of language, or cultural practice-was not a barrier to cultural continuity. This exhibition was utilised as a way to teach cultural competencies to first-year medical students who would later interact with Wiradjuri and others as medical doctors.

One of the more participatory and engaged methods of starting the process of honouring IKs will be by extending the success of the Campus Flora project and implementing Indigenous landscape design surrounding the new Chau Chak Wing Museum building. The groundwork evident in the Campus Flora app development offers ways to embed the knowledge of the Gadigal people, and to imbue the museum spaces with this knowledge in ways that have the potential to engage the community at large. Landscape design that does not resonate with the traditional knowledges and offer inclusive narratives is not an option. Rather, we, the authors, are taking this opportunity to use the plants in the landscape around the new museum to connect the community to Indigenous languages, the scholarship of language reconstruction and

\footnotetext{
${ }^{5}$ The significance and importance of the Wiradjuri cultural revival projects in New South Wales, including the Dhaga Ngiyahni Ngan.Girra exhibition, cannot be underestimated. A pivotal moment in Australian history occurred on 7 September 2016 as Wiradjuri leader Linda Burney became the first Aboriginal woman to be elected to the Lower House of the Australian Parliament. Linda wore a Kangaroo skin cloak made by Lynette Riley depicting her ancestors' journey as well as Linda's own contemporary experience. Lynette Riley sang in Wiradjuri language as Linda gave her maiden speech, demonstrating the evocative power of our Indigenous languages as assertions of modern Aboriginal and Torres Strait Islander cultural identity.
} 
the curriculum. In doing so, we will be extending the learning spaces for education programmes to include the whole university campus (Cheung, Wardle, \& Quinnell, 2015). Landscaping for the University's new Chau Chak Wing Museum prioritises plants that will be used in the museum's education programmes. These plants and information on their education importance will be integrated into the Campus Flora app post-construction.

In exploring the different layers of information embedded in the plant species that are being built into the campus landscaping plans for the new museum, it becomes apparent that particular plant species from the Sydney region are becoming conduits between Aboriginal knowledge systems and philosophies. The environment stimulates human behaviour to elicit a deep appreciation of the cultural histories embedded in and represented by the campus flora.

\section{Case Study 3: The Built Environment}

The University's grounds continue to change, which offers new opportunities to convey meaning through Indigenous narrative. A powerful demonstration of language reclamation and revitalisation is demonstrated on the façade of the new Faculty of Arts and Social Sciences building on the University's Camperdown campus. The work, GARABARA, by Yawuru (Western Kimberley) artist Robert Andrew, is an embodiment of the consultative and collaborative approach that this type of work requires (see Fig. 12.3). Gadigal Elders, the Metropolitan Local

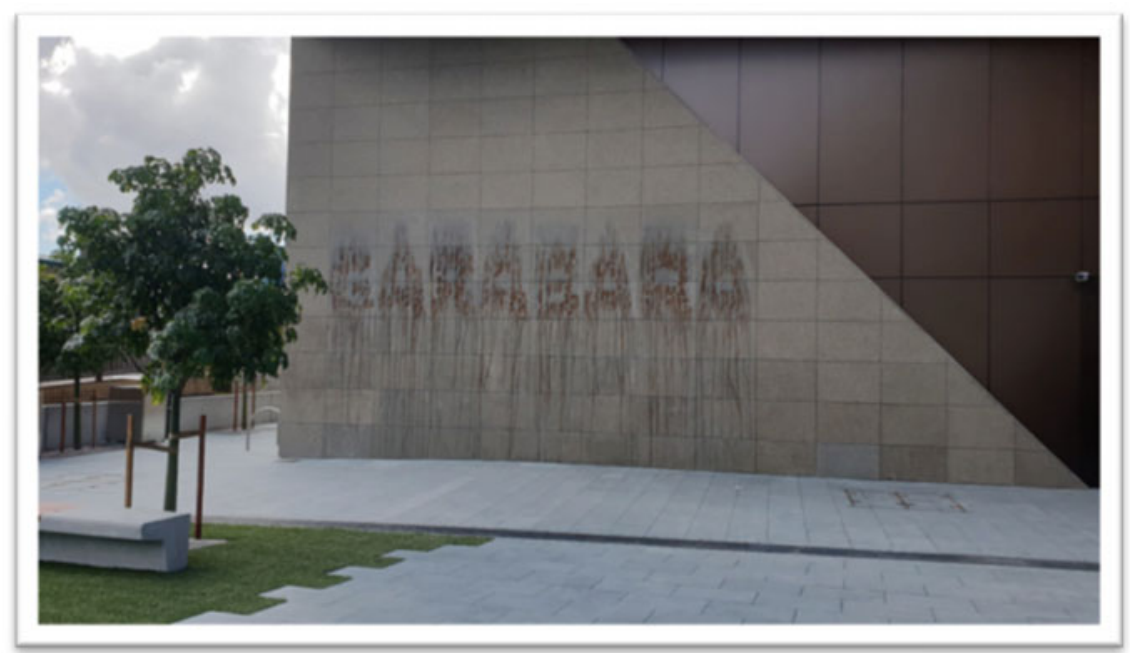

Fig. 12.3 Robert Andrew's work, GARABARA, installed at the new Faculty of Arts and Social Sciences building (Photo credit R. Quinnell @The University of Sydney) 
Aboriginal Land Council, University Indigenous staff and the Campus Infrastructure Services navigated a respectful integration of the final work into the built environment. The artist captured this well in his description of his process in researching and making the work:

Corroboree (ca-rib-ber-re), Garabara, Korobra has its origins in the local indigenous language of the Sydney area. The word Garabara and all its known and unknown meanings look at knowledge that is continually accessed, uncovered, enacted/re-enacted, read and interpreted, often displaced and replaced, always moving and always growing (Andrews, from Stephen, 2018)

\section{Concluding Remarks}

The sharing of knowledge has been a continuing tradition on the lands upon which the University of Sydney is built and where students and teachers have assembled for many thousands of years. The initiatives described above have enabled the extension of available learning spaces to the whole University campus, to be used for education programmes (Quinnell, 2015). All members of our campus community have available to them the means of being on Gadigal land and reconnecting the Aboriginal names of plants from Sydney with the plants themselves. This is a physical embodiment of cultural competence, and it now extends from the landscape to the built environment. A better and deeper understanding of Indigenous languages, and the names and the taxonomies and all the plant and species names, has been absorbed across the Chau Chak Wing Museum. The International Year of Indigenous Languages began 1 January 2019 and offers an important international focus and a means to engage with and honour Australia's Indigenous cultures. Adopting approaches where Aboriginal and non-Aboriginal members of a campus community can be part of the process of language revitalisation is proving to be a powerful strategy for enacting cultural change.

\section{References}

Attenbrow, V. (2009a). Clan names chart. Retrieved from https://australianmuseum.net.au/clannames-chart\#sthash.2HeaADqa.dpuf.

Attenbrow, V. (2009b). Aboriginal place names around Port Jackson and Botany Bay, New South Wales, Australia. In H. Koch \& Hercus L. (Eds.), Aboriginal placenames: Naming and re-naming the Australian landscape (pp. 8-54). Canberra: ANU E Press.

Australian Academy of Science. (2010). Academy 2010 election statement: Empower science, power the future. Retrieved from https://www.science.org.au/supporting-science/science-pol icy/submissions-government/statement $\%$ E2\% $80 \% 942010$-election-statement-empower\#sthash. nqX541kB.dpuf.

Australian Bureau of Meteorology. (2014). Indigenous weather knowledge. Retrieved from http:// www.bom.gov.au/iwk/climate_culture/Indig_seasons.shtml. 
Australian Museums and Galleries Association. (2017). First peoples: A roadmap for enhancing indigenous engagement in museums and galleries. Retrieved from https://www.mgaindigenousro admap.com.au/.

Bowern, C., \& Atkinson, Q. (2012). Computational phylogenetics and the internal structure of Pama-Nyungan. Language, 88(4), 817-845.

Brown, L. (2013). Storytelling and ecological management: Understanding kinship and complexity. Journal of Sustainability Education, 4, 1-6. Retrieved from: www.jsedimensions.org.

Cheung, C., Wardle, G., \& Quinnell, R. (2015). Campus Flora: A digital education and engagement tool to turn whole campuses into interactive learning spaces. Bulletin of the Ecological Society of Australia, 45(3).

Collins, D. (1798). An account of the English Colony in New South Wales (vol. 1). T. Cadell Jun. \& W. Davies: London.

Cook, J., \& Wharton, W. (1893). Captain Cook's journal during his first voyage round the world made in H.M. Bark Endeavour, 1768-71: A literal transcription of the original mss. London: Elliot Stock.

Dawes, W., Rayner, S., \& Brown, S. (2009). William Dawes: Notebooks on the Aboriginal language of Sydney: a facsimile version of the notebooks from 1790 to 1791 on the Sydney language written by William Dawes and others. London: SOAS.

Dimon, R., Pettit, L., Cheung, C., \& Quinnell, R. (2019). Promoting botanical literacy with mApps using an interdisciplinary, student as partners approach. International Journal for Students as Partners, 3(2), 118-128.

Fernández-Llamazares, Á., \& Cabeza, M. (2018). Rediscovering the potential of indigenous storytelling for conservation practice. Conservation Letters, 11, 1-12.

Griffiths, B. (2015). An aboriginal history of The University of Sydney. Retrieved from https://downcitystreets.files.wordpress.com/2015/09/billy-griffiths_an-aboriginal-historyof-the-university-of-sydney.pdf.

Hobson, J., Lowe, K., Poetsch, S., \& Walsh, M. (2010). Reawakening Australian Languages. In J. Hobson, K. Lowe, S. Poetsch, \& M. Walsh (Eds.), Re-awakening languages: Theory and practice in the revitalisation of Australia's Indigenous languages (pp. 25-30). Sydney: Sydney University Press.

Maier, S. (2010). Establishing a school language program: the Parkes High School experience. In J. Hobson, K. Lowe, S. Poetsch, \& M. Walsh (Eds.), Re-awakening languages: Theory and practice in the revitalisation of Australia's Indigenous languages (pp. 210-215). Sydney: Sydney University Press.

Martin, K., \& Mirraboopa, B. (2003). Ways of knowing, ways of being and ways of doing: Developing a theoretical framework and methods for Indigenous and Indigenist research. Journal of Australian Studies, 27, 203-214.

National Centre for Cultural Competence. (2016, 14 October). Our commitment. Retrieved from http://sydney.edu.au/nccc/about/index.shtml.

National Museum of Australia. (2014). Collaborating for Indigenous Rights. Charles Perkins. Australian Government Agency. Retrieved from http://www.nma.gov.au/indigenous/people/pag ination/charles_perkins.

Nugent, M. (2013). Sites of segregation/sites of memory: Remembrance and "race" in Australia. Memory Studies, 6, 299-309.

Pearson, M., Marshall, D., Ellsmore, D., Attenbrow, V., Rosen, S., Kerr, R., \& Betteridge, C. (2002). University of Sydney grounds conservation plan. Retrieved from https://sydney.edu.au/content/ dam/corporate/documents/about-us/campuses/grounds-conservation-plan-appendices.pdf.

Pettit, L., Pye, M., Wang, X., \& Quinnell, R. (2014a). Supporting botanical literacy in the undergraduate science curriculum and beyond with a bespoke campus App. Paper presented at the Australian Conference for Science and Mathematics Education, The University of Sydney. 
Pettit, L., Pye, M., Wang, X., \& Quinnell, R. (2014b). Designing a bespoke App to address botanical literacy in the undergraduate science curriculum and beyond. In B. Hegarty, J. McDonald, \& S.K. Loke (Eds.), Ascilite rhetoric and reality: Critical perspectives on educational technology (pp. 614-619). Dunedin.

Poll, M., Hughes, M., South, B., \& Angeles, S. The University of Sydney (Producer). (2018, August 27). Sydney ideas. Being Collected: insights into repatriation: Behind the scenes of the good news stories of repatriation. Retrieved from https://soundcloud.com/sydney-ideas/being-collected-ins ights-into-repatriation.

Poll, M. (2015). Written in stone. Macleay Museum, The University of Sydney. 17th August 20158th August 2016.

Quinnell, R. (2015, 25-28 October). The CampusFlora App project. Paper presented at the 7th BGANZ Congress "Connecting with Communities," Novotel, Wollongong.

Quinnell, R., Troy, J., \& Poll, M. (2018). The Sydney language in our curriculum. Paper presented at Cultural Competence and the Higher Education Sector: Dilemmas, Policies and Practice, The University of Sydney.

Reid, J. (2010). The rebirth of Wergaia: a collaborative effort. In J. Hobson, K. Lowe, S. Poetsch, \& M. Walsh (Eds.), Re-awakening languages: Theory and practice in the revitalisation of Australia's Indigenous languages (pp. 210-215). Sydney: Sydney University Press.

Reid, N., Nunn, P., \& Sharpe, M. (2014). Indigenous Australian stories and sea-level change. Paper presented at Indigenous Languages: Value to the Community, Okinawa International University, Okinawa, Japan. Retrieved from http://research.usc.edu.au/vital/access/manager/Repository/usc: 14264 ?queryType=vitalDismax \&query=indigenous+australian+stories.

Reily, L., \& Reily-McNaboe, D. (2014). Dhaga Ngiyahni. Ngan.Girra (where we all meet). 25 May-1, August, 2018. Macleay Museum. The University of Sydney. Retrieved from http://syd ney.edu.au/museums/exhibitions-events/where-we-all-meet.shtml.

Sherwood, J., \& Russell-Mundine, G. (2017). How we do business: Setting the agenda for cultural competence at The University of Sydney. In J. Frawley, S. Larkin, \& J. Smith (Eds.), Indigenous pathways, transitions and participation in higher education. Springer Open: Singapore.

Simpson, M. (2009). Museums and restorative justice: Heritage, repatriation and cultural education. Museum International, 61, 121-129.

Stephen, A. P. (2018). Garabara, old knowledge's new learnings. MUSE, 20(June), 10-12.

The University of Sydney. (2016a). The University of Sydney 2016-2020 strategic plan.

The University of Sydney. (2016b). Wingara Mura design principles. Retrieved from https://syd ney.edu.au/documents/about/working-with-us/wingara-mura-design-principles.pdf.

The University of Sydney. (2012). Wingara Mura-Bunga Barrabugu: The University of Sydney Aboriginal and Torres Strait Islander Integrated Strategy. Retrieved from http://sydney.edu.au/ strategy/docs/wingara-mura-bunga-barrabugu.pdf.

Troy, J. (1992). The Sydney Language notebooks and responses to language contact in early colonial NSW. Australian Journal of Linguistics, 12(1), 145-170. https://doi.org/10.1080/072686092085 99474.

Troy, J. (1994). The Sydney language. Flynn, ACT: J. Troy.

Troy, J. The University of Sydney (Producer). (2018, March 15). Sydney Ideas. Interlocutors in the archive: Aboriginal women and the collection of anthropological data. Retrieved from: https://soundcloud.com/sydney-ideas/interlocutors-in-the-archive-aboriginal-women-andthe-collection-of-anthropological-data.

Troy, J., \& Poll, M. The University of Sydney (Producer). (2018, May 18). Aboriginal and Torres Strait Islander Knowledges Seminar Series 1. History and Language. Retrieved from https:// www.youtube.com/watch?v=N3rdJS2bYj8.

Troy, J., \& Walsh, M. (2009). Reinstating aboriginal placenames around Port Jackson and Botany Bay. In H. Koch \& Hercus L. (Eds.), Aboriginal placenames: Naming and re-naming the Australian landscape (pp. 55-69). Canberra: ANU E Press. 
United Nations Educational, Scientific and Cultural Organization. (2016). UNESCO presents in New York 2019 International Year of Indigenous Languages. Retrieved from https://en.unesco. org/news/unesco-presents-new-york-2019-international-year-indigenous-languages.

United Nations Educational, Scientific and Cultural Organization. (2018). 2019 international year of indigenous languages. Retrieved from https://en.iyil2019.org/.

Universities Australia. (2011a). Guiding principles for developing Indigenous cultural competency in Australian Universities. Canberra: Universities Australia.

Universities Australia. (2011b). National best practice framework for Indigenous cultural competency in Australian Universities. Canberra: Universities Australia.

Walsh, M. (1993). Languages and their status in Aboriginal Australia. In M. Walsh \& C. Yallop (Eds.), Language and culture in Aboriginal Australia (pp. 1-14). Canberra, ACT: Aboriginal Studies Press.

Walsh, M., Marmion, D., \& Troy, J. (2014). Re-awakening Australian languages: Economic, educational, health and social benefits to the community. In P. Heinrich \& N. Ostler (Eds.), Indigenous languages: Value to the community (pp. 107-112). Foundation for Endangered Languages: Japan.

Walsh, M. (2016). Ten postulates concerning narrative in Aboriginal Australia. Narrative Inquiry, 26(2), 193-216.

Rosanne Quinnell is an Associate Professor in Biology who also conducts research in education. She is interested in how students learn science and how best to use e- and m-innovations and interventions in the science curriculum. She has adopted a "students as partners" approach in a number of projects.

Jakelin Troy is Ngarigu of the Snowy Mountains, south-eastern Australia. She is Director, Indigenous Research, Office of the Deputy Vice-Chancellor (Research) at the University of Sydney. She is a linguistic anthropologist specialising in the Aboriginal languages of south-eastern Australia and is known for her work in supporting the renewal and maintenance of these highly endangered languages. Her work in reconstructing, from historical sources, the Aboriginal language of the Sydney region has contributed to its renewed vibrancy amongst its community.

Matthew Poll is an assistant curator with the Chau Chak Wing Museum Indigenous Heritage collections as well as the University of Sydney Repatriation Project Officer. Matt works predominantly across contemporary Aboriginal and Torres Strait community arts development projects that create empowered futures for living communities.

Open Access This chapter is licensed under the terms of the Creative Commons Attribution 4.0 International License (http://creativecommons.org/licenses/by/4.0/), which permits use, sharing, adaptation, distribution and reproduction in any medium or format, as long as you give appropriate credit to the original author(s) and the source, provide a link to the Creative Commons license and indicate if changes were made.

The images or other third party material in this chapter are included in the chapter's Creative Commons license, unless indicated otherwise in a credit line to the material. If material is not included in the chapter's Creative Commons license and your intended use is not permitted by statutory regulation or exceeds the permitted use, you will need to obtain permission directly from the copyright holder. 